\title{
Black shale deposition during Toarcian super-greenhouse driven by sea level
}

\author{
M. Hermoso ${ }^{1}$, F. Minoletti ${ }^{2,3}$, and P. Pellenard ${ }^{4}$ \\ ${ }^{1}$ University of Oxford - Department of Earth Sciences, South Parks Road, Oxford, OX1 3AN, UK \\ ${ }^{2}$ UPMC Université Paris 06 - UMR7193 ISTeP, 4 Place Jussieu, 75005 Paris, France \\ ${ }^{3}$ CNRS - UMR7193 ISTeP, 4 Place Jussieu, 75005 Paris, France \\ ${ }^{4}$ Université de Bourgogne, CNRS - UMR6282, Biogéosciences, 6 Boulevard Gabriel, 21000 Dijon, France
}

Correspondence to: M. Hermoso (michael.hermoso@earth.ox.ac.uk)

Received: 21 July 2013 - Published in Clim. Past Discuss.: 31 July 2013

Revised: 9 October 2013 - Accepted: 5 November 2013 - Published: 4 December 2013

\begin{abstract}
One of the most elusive aspects of the Toarcian oceanic anoxic event (T-OAE) is the paradox between carbon isotopes that indicate intense global primary productivity and organic carbon burial at a global scale, and the delayed expression of anoxia in Europe. During the earliest Toarcian, no black shales were deposited in the European epicontinental seaways, and most organic carbon enrichment of the sediments postdated the end of the overarching positive trend in the carbon isotopes that characterises the TOAE. In the present study, we have attempted to establish a sequence stratigraphic framework for Early Toarcian deposits recovered from a core drilled in the Paris Basin using a combination of mineralogical (quartz and clay relative abundance) and geochemical ( $\mathrm{Si}, \mathrm{Zr}$, Ti and $\mathrm{Al}$ ) measurements. Combined with the evolution in redox sensitive elements ( $\mathrm{Fe}, \mathrm{V}$ and $\mathrm{Mo}$ ), the data suggest that expression of anoxia was hampered in European epicontinental seas during most of the T-OAE (defined by the positive carbon isotope trend) due to insufficient water depth that prevented stratification of the water column. Only the first stratigraphic occurrence of black shales in Europe corresponds to the "global" event. This interval is characterised by $>10 \%$ Total Organic Carbon (TOC) content that contains relatively low concentration of molybdenum compared to subsequent black shale horizons. Additionally, this first black shale occurrence is coeval with the record of the major negative Carbon Isotope Excursion (CIE), likely corresponding to a period of transient greenhouse intensification likely due to massive injection of carbon into the atmosphere-ocean system. As a response to enhanced weathering and riverine run-off, increased fresh
\end{abstract}

water supply to the basin may have promoted the development of full anoxic conditions through haline stratification of the water column. In contrast, post T-OAE black shales during the serpentinum and bifrons Zones were restricted to epicontinental seas (higher Mo to TOC ratios) during a period of relative high sea level, and carbon isotopes returning to pre-T-OAE values. Comparing palaeoredox proxies with the inferred sequence stratigraphy for Sancerre suggests that episodes of short-term organic carbon enrichment were primarily driven by third-order sea level changes. These black shales exhibit remarkably well-expressed higher-frequency cyclicities in the oxygen availability in the water column whose nature has still to be determined through cyclostratigraphic analysis.

\section{Introduction}

Evidence for widespread oceanic anoxia during the Early Toarcian (183 Ma) relies heavily on sedimentological observation of organic-rich rocks (Jenkyns, 1988). However, as the record of these organic carbon-rich deposits is geographically restricted to the European epicontinental sea, their global significance cannot be ascertained with confidence, although some sections outside Europe reflecting more open oceanic conditions do seem to hint at a coeval organic carbon enrichment (Hori, 1997; Al-Suwaidi et al., 2010; Caruthers et al., 2011; Gröcke et al., 2011; Izumi et al., 2012). Several definitions of black shales have been used by various authors, as pointed out by McArthur et al. (2008). This problem has 
led to different interpretations pertaining to the stratigraphic relationship between "black shale" occurrence and the carbon isotope curves. In the present study, we define a black shale interval on the basis of sediment lamination rather than a TOC content higher than $5 \%$ (Neuendorf et al., 2005). Indeed, the organic content may be modulated as a result of dilution by clay and carbonate minerals. The Sancerre borehole drilled in the southern Paris Basin (Fig. 1) has provided invaluable information on the record of the negative CIE and its relation with the T-OAE (Hermoso et al., 2009a, b, 2012). In this core section, such laminated intervals, however, systematically exhibit $>2 \%$ TOC and an appreciable amount $(\sim 3 \%)$ of pyrite.

A remarkable positive trend in carbon isotope ratios $\left(\delta^{13} \mathrm{C}\right)$ testifies for intense and widespread organic carbon burial during the Early Toarcian. Recent geochemical developments support the idea of global scale anoxia (Pearce et al., 2008; Lu et al., 2010; Gill et al., 2011). In most documented European sections, black shale intervals are recorded after the termination of the positive carbon isotope shift and thus, their global nature is disputable. This discrepancy, and how various authors have defined "black shales", has led to the concept of Regional OAEs or R-OAE (McArthur et al., 2008).

Another prominent event recorded at the onset of black shale deposition in Europe is the pronounced negative carbon isotope excursion (CIE) superimposed upon the $\delta^{13} \mathrm{C}$ positive shift (Hesselbo et al., 2000). This sharp isotopic event, reflecting injection of isotopically-light carbon into the ocean-atmosphere system, is near-synchronous with the base of the black shales in European basins suggesting a causal link (Hesselbo et al., 2000). As stated in the review paper by Jenkyns (2010), "The early Toarcian OAE has [...] a positive excursion with an abrupt negative "bite" in its central portion". Indeed, the T-OAE and the T-CIE refer to distinct concepts, because they correspond to very different palaeoceanographic events in terms of both nature and timing. This observation, and the fact that anoxia and consecutive organic carbon burial led to a positive drift in $\delta^{13} \mathrm{C}$, justify our stratigraphic definition of the T-OAE that utilises the overarching positive carbon isotope trend as done by Woodfine et al. (2008) and Hermoso et al. (2012). Furthermore, adopting such a chemostratigraphic definition of the Early Toarcian OAE may enable stratigraphic correlation between coeval sections, as the stratigraphic extension of black shales deposited in relatively shallow waters is likely to be diachronous (Wignall et al., 2005).

A causal link between amplification of a greenhouse period concomitant with the CIE and initiation of anoxic/euxinic conditions has been proposed by numerous authors (Hesselbo et al., 2000; Kemp et al., 2005; McElwain et al., 2005; Hermoso et al., 2009a, 2012). Detailed constraints on climatic evolution, sea level change and the degree of water column oxygenation that prevailed before, during and after the OAE have yet to be obtained, despite

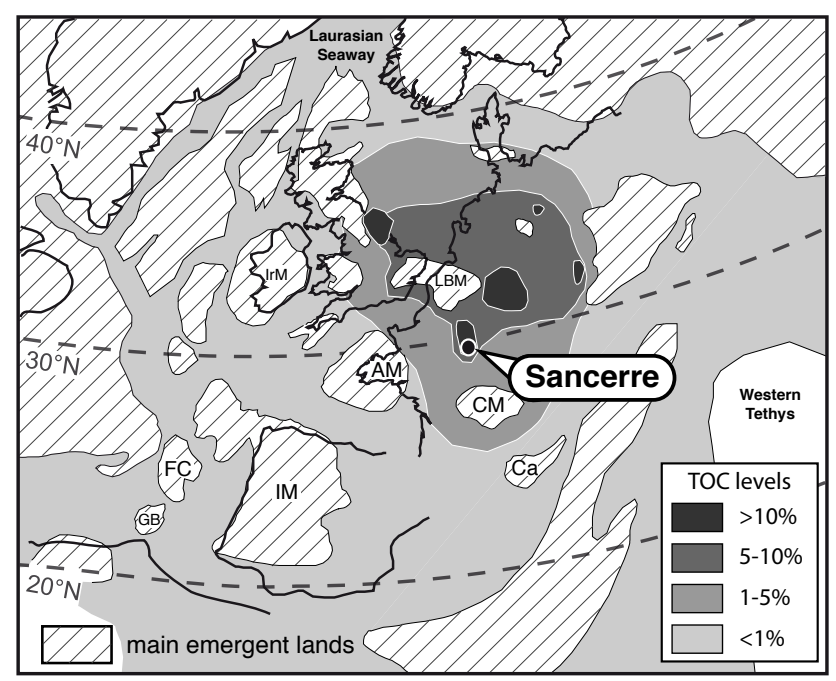

Fig. 1. Palaeogeographic map of the Early Jurassic archipelago, and the geographic distribution of organic-rich rocks. Greyscale shades indicate the content range of Total Organic Carbon (TOC); key is embedded bottom right. Emergent land delineating the basins are hatched: IrM for Irish Massive; LBM for London-Brabant Massif; AM for Armorican Massif; CM for Central Massif; Ca for Calabria; IM for Iberian Meseta; FC for Cap Flemish; and GB for Galicia Bank. The map indicates the location of the Sancerre borehole. Figure taken from Hermoso et al. (2009b).

their clear importance for understanding development of an oceanic anoxic event and subsequent Earth system recovery. The conjunction of a long-term event, the T-OAE that was recorded during three ammonite Zones, and a rapid and transient carbon isotope perturbation, the T-CIE that lasted less than $500 \mathrm{kyr}$ (Kemp et al., 2011) represents an invaluable archive to unravel the Jurassic Earth's system dynamics.

This new study on an extended stratigraphic interval of the Sancerre core aims to constrain the evolution of (i) the relative sea level through the establishment of a sequence stratigraphy framework; and (ii) the degree of water column oxygenation inferred by the concentration of redox-sensitive elements such as $\mathrm{Mo}, \mathrm{Fe}$, and V.

\section{Methods}

The present study presents a detailed mineralogical and geochemical record for the Late Pliensbachian, the whole Early Toarcian and the base of the Middle Toarcian intervals with a view to constraining the depositional settings leading to the expression of the successive black shale intervals. The highresolution records of carbonate, total organic carbon (TOC) contents, and stable isotopes from previous studies (Hermoso et al., 2009, 2012) have been stratigraphically extended to better constrain the Pliensbachian-Toarcian boundary and to document the top of the serpentinum and the bifrons Zones. 
Determination of concentration of a suite of metals was performed by X-Ray Fluorescence (XRF) using a Thermo Scientific Niton XL3t GOLDD+ apparatus. The resolution step was $10 \mathrm{~cm}$. Standardisation of the raw data expressed in counts per seconds to elemental concentrations was obtained by the "Mining" mode of the instrument, which corresponds to the setting suitable for sediment measurements and expression of the results in ppm of elements. Further correction of the results was achieved by measuring nine certified standards provided by Niton UK Ltd. For all major elements (Al, $\mathrm{Si}, \mathrm{Zr}$ and $\mathrm{Ti}$ ), the typical error associated to the measurement is less than $5 \%$ based on replicated standards. For Mo and $\mathrm{V}$, the error is greater and depends on the TOC content. The Limits of Detection (LOD; Fig. 4) for these elements are $\sim 5$ and $15 \mathrm{ppm}$, respectively. The typical error is in the order of $10 \%$. Mo was not detected in samples yielding less than $2 \%$ TOC.

Quantification of the calcite/dolomite ratio was performed by X-Ray Diffractometry (XRD) from finely powdered samples using a Brucker D4 diffractometer with $\mathrm{CuK} \alpha$ radiation and Ni filter at University of Bourgogne. The relative proportion of the insoluble phases (mostly consisting of quartz, pyrite and clays) was determined from XRD diagrams from decarbonated $(10 \% \mathrm{HCl})$ samples. As pyrite and quartz minerals have good diffractive properties (cf the Powder Diffraction File database by the International Centre for Diffraction Data), the error associated to their quantification by XRD is less than 5\%. The Quartz/(Quartz + Clay) index was determined by measuring the area of the peak (101) of quartz and those of all well-identified (001) peaks of clay minerals (illite, chlorite, kaolinite). In the Sancerre sediments, no radiolarians or sponge spicules were observed. Occurrence of radiolarians during the Jurassic seems to be confined in distal or oceanic environments (De Wever and Baudin, 1996; Carter et al., 2010). There were no diatoms either as they appeared later in the fossil record. This absence of biogenic silica in the samples allows using the measured quartz concentration as reflecting a coarse detrital signal.

Total organic (TOC) and inorganic (TIC) carbon contents, and the isotopic composition of carbonate were measured at Oxford following the procedures described in Hermoso et al. (2012). TIC and TOC contents were measured by coulometric titration using a Strohlein Coulomat 702. To obtain the carbonate abundance of sediments derived from the TIC content $(\%$ Carbonate $=8.3 \times$ TIC), $100 \mathrm{mg}$ of finely powered sample were roasted at $420^{\circ} \mathrm{C}$ for $12 \mathrm{~h}$ in order to remove the organic matter, and subsequently analysed in the instrument. Total carbon content (TIC + TOC) was measured from $50 \mathrm{mg}$ non-treated samples. Reproducibility of measurements was usually better than $0.1 \%$. Samples were measured for their carbon and oxygen isotopes using a VG Isogas Prism II mass spectrometer with an on-line VG Isocarb at Oxford University. An approximate mass of $50 \mathrm{mg}$ of finely crushed samples was reacted with anhydrous phosphoric acid at $90^{\circ} \mathrm{C}$. Calibration to V-PDB standard is made using the
NOCZ internal standard. Reproducibility of the analyses is generally better than $0.1 \%$ for carbon and oxygen isotopes.

\section{Results and discussion}

\subsection{Occurrence of black shale intervals at Sancerre}

The total thickness of the Early/Middle Toarcian black shales in the core is approximately $40 \mathrm{~m}$ (Lorenz, 1987; Hermoso et al., 2009a). In details, on the basis of sediment lamination, high abundance of organic carbon $(>2 \%)$, and pyrite $(>3 \%)$ content, four discrete black shale intervals can be distinguished in the Sancerre core. They are termed Sc1, Sc2, and $\mathrm{Sc} 3$ for those occurring in the Schistes carton Fm in the Early Toarcian, and Mb1 in the Marnes à Bifrons Fm in the Middle Toarcian (Fig. 2).

The interval Sc1, ranging from 348.25 to approximately $344.60 \mathrm{~m}$, represents substantial organic carbon enrichment with TOC reaching $11 \%$. Because it is closely associated to the negative CIE, this first black shale interval has been extensively studied (Hermoso et al., 2012). This is the only black shale interval that is expressed during the T-OAE, as isotopically defined. It has to be emphasised that prior to $\mathrm{Sc} 1$, the first step of the CIE is recorded within a thin interval of organic carbon enrichment (2.5\% TOC), but no sediment lamination is observed. The onset of $\mathrm{Sc} 1$ is contemporaneous with the second step of the CIE. The termination of $\mathrm{Sc} 1$ is expressed during, and probably caused by a period of bottom water reoxygenation as evidenced by sediment bioturbation and relatively low sulphur (pyrite) content between 344 and $342 \mathrm{~m}$ (Fig. 2). The black shale interval Sc2 shows relatively low pyrite content and a notable decrease in the carbonate content. The TOC are lower than recorded within Sc1, $\sim 5 \%$ in average with maxima at $8 \%$. The boundary between $\mathrm{Sc} 2$ and Sc3, placed at approximately $335 \mathrm{~m}$, is not as clear as that distinguishing $\mathrm{Sc} 1$ from Sc2. However, this horizon shows sediment bioturbation. Sc3 represents comparable organic carbon enrichment with respect to $\mathrm{Sc} 2$ but the pyrite content is, on average, higher in the former black shale interval $(4-5 \%)$. The fourth black shale interval $(\mathrm{Mb} 1)$ is marked by lower concentration of TOC, carbonate and pyrite, although the sediments remain continuously laminated. The late Early Toarcian (top of serpentinum Zone) and Middle Toarcian sediments correspond to very argillaceous deposits.

\subsection{Establishing a sequence stratigraphy framework for the Sancerre deposits}

Establishing a sequence stratigraphy for the Early Toarcian has proven to be relatively difficult owing to the poor expression of cycles in the lithology (Hesselbo, 2008). Another complication of the present study was that the facies of sedimentary rocks and lithological contrasts between genetic units retrieved in cores is usually less visible than in coeval outcrops on land. The recognition of transgressive-regressive 


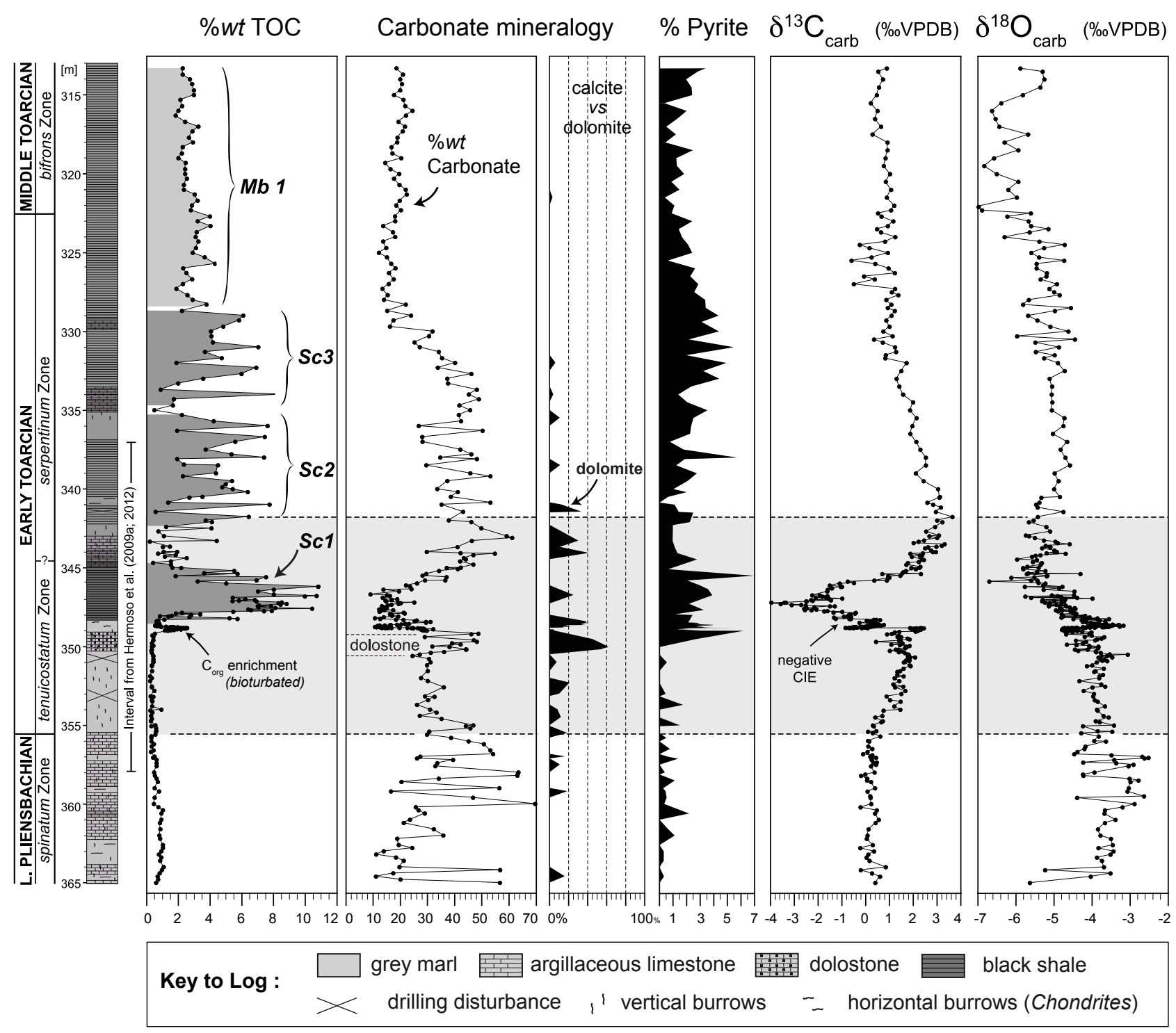

Fig. 2. Organic carbon enrichments for the Late Pliensbachian-Middle Toarcian interval of Sancerre core. From left to right: Total Organic Carbon (TOC), carbonate content and calcite to dolomite ratio, pyrite content, and bulk carbon $\left(\delta^{13} \mathrm{C}_{\text {carb }}\right)$ and oxygen $\left(\delta^{18} \mathrm{O}_{\text {carb }}\right)$ isotope ratios. Isotopic data in the interval from 358 to $337 \mathrm{~m}$ are predominantly from previous studies on this core material (Hermoso et al., 2009a, 2012). Based on the abundance of TOC, pyrite and presence of lamination of the sediments, four successive black shale intervals are recognised (Sc1, Sc2, Sc3 and Mb1). Only the first black shale interval $(\mathrm{Sc} 1)$ is recorded within the positive trend in $\delta^{13} \mathrm{C}(\mathrm{T}-\mathrm{OAE})$. The onset of the first black shale is stratigraphically associated with the second step of the negative CIE and is accompanied by a pronounced decrease in the $\delta^{18} \mathrm{O}$. Subsequent (post T-OAE) black shales are not synchronous with isotopic events. The biostratigraphic framework is from Lorenz (1987).

cycles across the Late Pliensbachian to Middle Toarcian interval in this study was determined using a combination of biostratigraphic, sedimentological, mineralogical and geochemical observations and measurements (Fig. 3).

\subsubsection{Second-order cycle: the Liassic transgression}

A major, second-order (sensu de Graciansky et al., 1998) sea level rise occurred during the Early Jurassic and is classically attributed to tectonoeustasy (Guillocheau et al., 2000; Hallam, 2001). The stratigraphic position of the base of this cycle T6 is resolved using the biostratigraphic framework and the sedimentology of the Sancerre deposits (Fig. 3). This Maximum Regressive Surface (MRS R5-T6) records an abrupt change in the lithology from sandy limestone (rich in macrofossils) to dark grey calcareous marlstone. In most regions of the NW European realm, this surface has led to the absence of the latest Pliensbachian and earliest Toarcian 


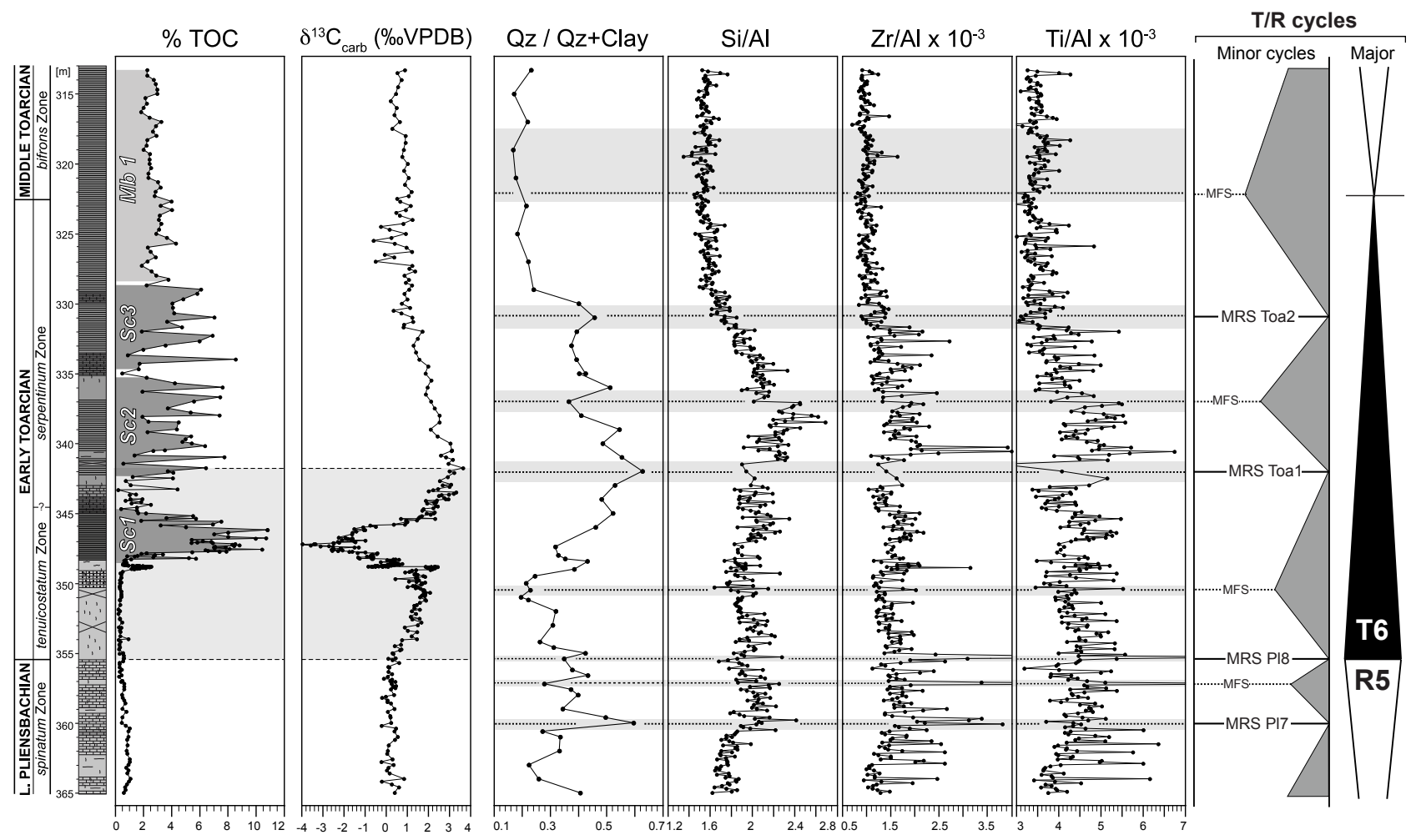

Fig. 3. Evolution in the $Q z / Q z+$ Clay ratio, concentration of detrital elements ( $\mathrm{Si}, \mathrm{Zr}, \mathrm{Ti}, \mathrm{Al}$ ), and attempt of a sequence stratigraphy framework throughout the successive black shale intervals. Representation of eustatic cycles and the name of these cycles on the right of the figure are inspired from de Graciansky et al. (1998). Major and minor cycles correspond to second- and third-order cycles, respectively. MFS is for Maximum Flooding Surface; MRS for Maximum Regressive Surface ( Sequence Boundary). Horizontal dashed lines drawn within the grey boxes indicate a more precise position of key eustatic surfaces using geochemical elements.

sediments corresponding to a major sedimentary hiatus at the stage boundary (Morard et al., 2003; Hermoso et al., 2009b). The MFS of T6 occurred around the serpentinum-bifrons Zonal transition (= limit between the Early and Middle Toarcian) in the Paris Basin (Gély and Lorenz, 2006; Guillocheau et al., 2000), and can be placed at Sancerre at approximately $322 \mathrm{~m}$, within the clayed facies of the Marnes à Bifrons Fm (Figs. 2 and 3).

\subsubsection{Third-order eustatic cycles}

The relative proportion of coarse versus fine detrital fractions of the sediment (represented by quartz and clay minerals, respectively) deposited at a given location is driven by accommodation space, and, consequently by the shoreline position (Williams et al., 2001; Coe, 2003). This sequence stratigraphic feature is typically used to recognise patterns in relative sea level change (de Graciansky et al., 1998; Williams et al., 2001; Coe, 2003; Hesselbo, 2008). Indeed, changes in the distance between the studied location and the coastline where sediments are supplied may be attributable to sea level assuming no significant change in the source of detrital supply, nor variation of the subsidence rate (Guillocheau et al., 2000). The base of each third-order cycle, called Sequence
Boundary (SB) is approximated by the position of the MRS and detected by maxima in the $Q z / Q z+$ Clay curve. The end of the transgression represented by the Maximum Flooding Surface (MFS) corresponds to highest relative proportion of clays (i.e. to low value in $Q z / Q z+$ Clay curve).

The lowest part of the studied interval in the Pliensbachian corresponds to the end of the regression of cycle Pl6 and terminates at $360 \mathrm{~m}$ where a prominent peak in the proportion of quartz is recorded (Fig. 3). This level corresponds to the MRS Pl7. The uppermost Pliensbachian sediments record cycle the $\mathrm{Pl7}$, with a probable position of the MFS at $357 \mathrm{~m}$. The end of this third-order regression is contemporaneous with that of the R5 (second-order) cycle, both leading to the sedimentary unconformity that characterises the Pliensbachian-Toarcian boundary. It may appear surprising that the stage boundary, characterised by a prominent hiatus in the European record, is only seen with a relatively small peak in the $Q z / Q z+$ Clay curve compared to other key surfaces (Fig. 2). First, the MRS P18 surface is bracketed between an increase and a decrease in $Q z / Q z+$ Clay ratios, respectively indicating relative sea level fall and rise. Secondly, the absence of a prominent, albeit existing, peak may be explained by the hiatus itself, as it is likely that 
sediments were either not deposited or partly eroded during this interval.

In the Toarcian, the subsequent transgression (second- and third orders) is seen with decreasing $Q z / Q z+$ Clay ratios up to the MFS P18. This relative high sea level and maximum distance to the coast correspond to a minimum of coarse sedimentation at $350.50 \mathrm{~m}$. It is worth noting that this level stratigraphically corresponds to the base of the dolostone. The termination of this first intra-Toarcian eustatic cycle is followed by relatively coarse detrital sedimentation interval between 342 and $341 \mathrm{~m}$. In the serpentinum Zone, this MRS represents another notable sedimentary unconformity as evidenced by a stepwise change in all the detrital elements normalised to aluminium (Fig. 3). The transgression of the subsequent cycle, Toa1, terminates at the level of the MFS associated with a bioturbated interval $(336-335 \mathrm{~m})$. Substantial enrichment in fine detrital material followed during the transgressive portion of Toa2. The coincidence of the second and third order cycle in the depositional setting is here illustrated by the considerable amount of clay across Toa2 as a consequence of maximum distance of Sancerre to the coastline. Lower TOC contents $(\sim 3 \%)$ in Mb1 can be explained by enhanced riverine run-off with accompanying lower $\delta^{18} \mathrm{O}$, and dilution of pelagic sedimentation by clay minerals (see Sect. 3.3.4).

\subsection{Sea level and degree of oxygen depletion across the early and middle Toarcian}

\subsubsection{Earliest Toarcian transgression}

The earliest Toarcian sediments record sea level rise that terminates at the base of the dolostone $(350.50 \mathrm{~m})$. The $\mathrm{V} / \mathrm{Al}$ and $\mathrm{Fe} / \mathrm{Al}$ ratios are relatively stable in the lower part of the studied interval, and Mo was even not detected in sediments prior to Sc1, due to the relatively low organic carbon contents in the facies (typically less than $1.5 \%$ TOC). The geochemistry of the pre-Sc1 interval and the presence of sediment bioturbation concomitantly indicate that the water column was not anoxic during the Early Toarcian in the Paris Basin.

At the end of this transgression, enhanced precipitation of dolomite may have been favoured by deepwater starvation and reduced sedimentation rate, a characteristic of MFSs (Coe, 2003). Hence, the peak in the Fe/Al curve expressed within the dolostone is attributable to high dolomite content as this phase bears an appreciable amount of Fe (Hermoso et al., 2009b).

Stratigraphically above, the thin organic-rich interval associated to the first step of the CIE ( $\sim 349$ m; Figs. 1 and 4$)$ is not recorded with increased V, Fe or Mo contents. Hence, we cannot infer more anoxic conditions during the deposition of this relatively TOC-rich (about $3 \%$ ), albeit bioturbated, interval.

\subsubsection{Black shale interval Sc1}

A clear peak in $\mathrm{V} / \mathrm{Al}$ ratios is observed within $\mathrm{Sc} 1$. As the scavenging of vanadium is promoted with seawater anoxia, the concentration of $\mathrm{V}$ and the $\mathrm{V} / \mathrm{Al}$ ratio are commonly used to retrace the strength of oxygen depletion in the water column (Tribovillard et al., 2006). During this black shale interval, maximum $\mathrm{V} / \mathrm{Al}$ ratios were reached when maximum $p \mathrm{CO}_{2}$ is registered on the basis of isotopic $\left(\delta^{13} \mathrm{C}\right)$ evidence at $346.80 \mathrm{~m}$ (see Hermoso et al., 2012). This coincidence is suggestive of a link between $p \mathrm{CO}_{2}$ and oxygen demand in the water column through intense primary productivity. This level with maximum TOC enrichment of the whole studied section also displays clear peaks in the $\mathrm{Fe} / \mathrm{Al}$ (that cannot be explained by a mineralogical control) and Mo / OC ratios (Fig. 4). The Mo content normalised to the \% TOC can be used to diagnose widespread (low Mo/TOC) versus regionally restricted (high Mo/TOC) black shale deposition (Algeo and Lyons, 2006; Pearce et al., 2008). Compared to subsequent black shale facies, Mo/TOC is at a minimum in Sc1 possibly indicating widespread anoxia. Furthermore, given the high amount of pyrite recorded (3-5\%; Fig. 2), it is likely that the water column went not only anoxic, but also euxinic at that time.

With the termination of Sc1, a sharp subsequent decrease in $\mathrm{V} / \mathrm{Al}$ is observed with ratios returning to background and minimum values observed in the earliest Toarcian sediments. During this diminution in TOC content and $\mathrm{V} / \mathrm{Al}$ ratios, the $p \mathrm{CO}_{2}$ remained high, indicating that diminished DIC levels cannot explain the termination of the black shale interval Sc1 (McElwain et al., 2005; Hermoso et al., 2012). Hence, the end of Sc1 and reoxygenation of bottom waters are best explained by the sea level fall (regression of P18) re-establishing an insufficiently water column to allow stratification as it was the case before this black shale interval. Indeed, the bioturbated transition between $\mathrm{Sc} 1$ and Sc2 corresponds to the top of an upward-shallowing sequence.

The regressive surface at $342 \mathrm{~m}$ (MRS Toa1) is accompanied by a prominent hiatus in the sedimentary record as illustrated by peaks in all detrital elements (Fig. 3). This surface is also recognised in the well-studied Yorkshire succession where an important sedimentary hiatus has been suggested at the equivalent stratigraphic level (Jenkyns et al., 2002). It has to be noted that the Early Toarcian positive trend in $\delta^{13} \mathrm{C}$ terminates at this level, pinpointing the unconformity. Above this level, a long-term decrease in carbon isotope values is recorded up to the bifrons Zone. This stratigraphic level may hence denote the end of the widespread deposition of organic-rich facies.

\subsubsection{Black shale intervals Sc2 and Sc3}

The deposition of black shale Sc2 overlays the sedimentary unconformity at $342 \mathrm{~m}$, and subsequent in relative sea level raise (Toa1) is accompanied by progressive increases 

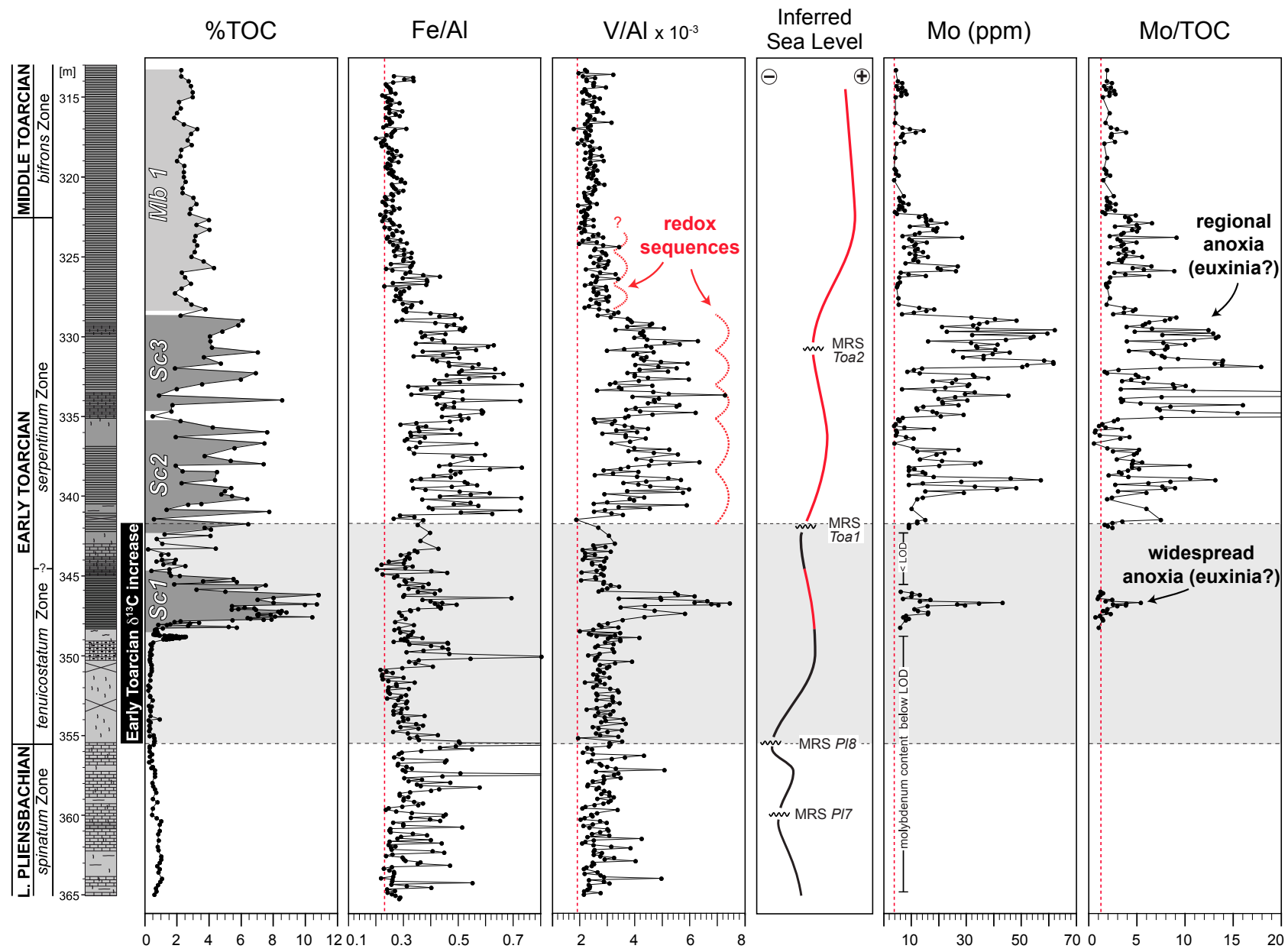

Fig. 4. Evolution in the concentration of redox-sensitive elements (Fe, V, Mo) and inferred relative sea level curve throughout the successive black shale intervals. A peak in V/Al is coincident with the expression of Sc1 after steady and low values during the earliest Toarcian. Subsequently, both Fe/Al and V/Al curves show relative high levels, similar fluctuations throughout Sc2-Sc3-Mb1 black shales, and allow recognition of tentative redox parasequences during the deposition of Sc2 and Sc3. The curve in the middle panel depicts the evolution of the relative sea level inferred from the sequence stratigraphy (Fig. 3). Red portions in the sea level curve on the right denote periods of relatively high water depth allowing water column stratification and full expression of anoxia. The Mo/TOC curve indicates widespread anoxic/euxinic conditions during deposition of $\mathrm{Sc} 1$. On the basis on the molybdenum content, it can be inferred that the subsequent black shales had more regional significance.

in $\mathrm{Fe} / \mathrm{Al}$ and $\mathrm{V} / \mathrm{Al}$ ratios. Both the curves show remarkable stacked cyclicities, which may reflect modulation in the oxygen availably in the water column (Fig. 4). The black shale interval Sc2 records highest ratios in Mo compared to Sc1, which, together with the decline in $\delta^{13} \mathrm{C}$, indicate a more geographically localised anoxia. The reoxygenation event between $\mathrm{Sc} 2$ and Sc3, evidenced by sediment bioturbation, is seen with minimum $\mathrm{Fe} / \mathrm{Al}$ and $\mathrm{V} / \mathrm{Al}$ ratios at $\sim 335 \mathrm{~m}$. This transition was likely driven by the episode of sea level fall, subsequent to the MFS of cycle Toa1 (Figs. 3 and 4).

In Sc3, Fe/Al and V/Al re-increase reaching comparable ratios as recorded in Sc2. Furthermore, the cyclic pattern in both element is also recognised in $\mathrm{Sc} 3$. Mo/TOC values yield a maximum, about 3-times those measured in $\mathrm{Sc} 1$. This progressive stratigraphic evolution through $\mathrm{Sc} 1-\mathrm{Sc} 2-\mathrm{Sc} 3$ would indicate that the first black shale interval associated with the negative CIE corresponded to a widespread, probably global, episode of carbon deposition whereas the subsequent intervals were of less and less global significance (possibly restricted to the NW European seaways). Additionally, the constant diminution in $\delta^{13} \mathrm{C}$ ratios during the serpentinum Zone that mirrors the elevation in Mo/TOC provide compelling evidence for the end of widespread anoxic conditions at a global scale.

The transition between $\mathrm{Sc} 3$ and $\mathrm{Mb} 1$ is the only one to express transgression. The sediments remained continuously laminated making this transition less clear than the previous ones. The absence of reoxygenation across the MRS Toa2 can be explained by the maximum bathymetry owing to the 
maximum flooding of the epicontinental surfaces (proximity of the MFS of the second-order cycle T6).

\subsubsection{Black shale interval Mb1}

During the bifrons Zone, enhanced clay supply to the basin has been recognised at a regional scale (Dera et al., 2009). This time interval also corresponds to maximum flooding of the Paris Basin defined at both second and third-orders (Fig. 4), hence reinforcing the flux of silt over coarse detrital minerals at the site of deposition. As a result, lower $\mathrm{Fe} / \mathrm{Al}$, $\mathrm{V} / \mathrm{Al}$ and $\mathrm{Mo} / \mathrm{TOC}$ ratios have to be interpreted in terms of an attenuation of the signal by enhanced dilution by clay minerals and $\mathrm{Al}$ element. Similarly, the generalised decrease in the abundance in all the other phases (carbonate content, TOC and pyrite) from 330-328 $\mathrm{m}$ can be explained by higher fine detrital supply (Fig. 2). Persistent lamination throughout the whole Mb1 black shale and yet detectable Mo concentrations confirms sustained anoxic conditions during the Middle Toarcian in the Paris Basin.

\subsection{Implications for the T-OAE and conclusions}

In the European epicontinental seaways, as the Paris Basin in the Early Jurassic, nutrient supply and seawater alkalinity may have remained constantly high owing to the vicinity of emergent lands and the overall greenhouse period. This reasonable assumption originally made by Erba $(2004,2006)$ and subsequently by Hermoso et al. (2012) enables us to discuss the deposition of black shale intervals mainly in terms of fluctuation in redox conditions rather than in change in surface productivity.

During the earliest Toarcian in NW Europe, the water depth was modest allowing permanent mixing by winds and storms (Röhl et al., 2001). Such a physical oceanographic setting prevented the full expression of seawater anoxia (or euxinia) in epicontinental seas. At this stage, expression of the T-OAE was probably restricted to the deep and open ocean, where intense primary productivity, increase of the oxygen demand, and substantial export of organic carbon to the seafloor led to the deposition of black shale facies.

Associated with the first step of the CIE (and restricted to it), the TOC content transiently reaches $\sim 3 \%$ in bioturbated sediments (still without black shale expression). Restricted levels of oxygen, but no full anoxia, in the bottom water during this interval are testified by the presence of Chondrites burrows. The $\delta^{13} \mathrm{C} / \mathrm{TOC}$ inverse relationship, also observed for the second step of the CIE, suggests a link between emission of (isotopically light) carbon and enhanced organic carbon burial during Sc1. Subsequently, the second step of the CIE may have represented a tipping point driving seawater from dysoxia toward proper anoxia. Expression of anoxia was allowed by a sufficiently deep water column consecutive to the Pl8 transgression (Fig. 3). With the cumulative inputs of carbon into the atmosphere-ocean system, substantial reinforcement of anoxic conditions may explain why strongest oxygen depletion, evidenced by very high $\mathrm{V}$ and $\mathrm{Fe}$ contents, and maximum TOC occurred within the first black shale interval compared to the subsequent black shales. The first black shale interval is the only one that recorded enhanced input of fresh water, as expressed in the oxygen isotopes at Sancerre (although only a part of this shift may be attributable to warming), and in the osmium profile from the coeval stratigraphic interval in Yorkshire (Cohen et al., 2004). Taken together, this would indicate that the triggering of full anoxia at the base of Sc1 was allowed by the depth of the water column, but triggered by emplacement of a haline stratification regime.

The termination of the expression of "global" black shales in NW Europeans seas can be explained by a conjunction of factors as the drawdown of excess carbon by the continental weathering and carbon export to the seafloor, and by reoxygenation of the water column in a context of a relative sea level fall. Subsequent, post-OAE, black shales in the serpentinum Zone were deposited under a thicker water column, as it was likely the case in coeval European Toarcian sections. The onset of black shales occurred during a transgressive trend with re-increased $\delta^{18} \mathrm{O}$ values.

Multiple sites, yet all in Europe, show similar Mo/TOC ratios and trends. Indeed, comparable evolution in the extension of anoxia during the Toarcian has also been found in the composite section of Yorkshire (Pearce et al., 2008) and in the NE of the Paris Basin (Lézin et al., 2013) providing compelling evidence for a progressive reduction in the lateral repartitioning of black shale deposition at the scale of NW European seas. As an alternative explanation, increased Mo concentrations may reflect increasing strength in the connection between the basin and the open ocean leading to enhanced seawater Mo delivery and deposition at Sancerre. In both cases, sea level rise is the primary parameter driving Mo enrichment during the Early/Middle Toarcian.

The absence of clear cyclicities in the Mo record as they are visible in $\mathrm{Fe}$ and $\mathrm{V}$ curves may be explained by the significantly longer residence time of Mo in seawater with respect to highly reactive $\mathrm{Fe}$ and $\mathrm{V}$. These cycles may correspond to the modulation of oxygen availability in the water column at a higher frequency than third order sea level changes. As the present study does not address the nature of these cycles, further cyclostratigraphic work are required to identify both their duration and control. However, it is likely that these high-frequency cyclicities may correspond to the expression of eccentricity that is a common feature in the sedimentary record of Jurassic sequences (Kemp et al., 2005, 2011; Boulila et al., 2011).

McArthur et al. (2008) have suggested that the deposition of R-OAEs was driven by basinal restriction. Our study underpins that sufficient water depth is a prerequisite for anoxia and organic carbon accumulation and preservation on the seafloor, even in case of such episodes of lowered water mass circulation and water mass starvation. Generating such an 
unprecedented sequence stratigraphic framework at this time resolution for the Toarcian may enable better interpretation of the depositional setting during an oceanic anoxic event, and constrain stratigraphic correlations with coeval sections.

Acknowledgements. The authors owe thanks to Steve Wyatt and Norman Charnley (both at Oxford University) for all their help in the preparation and running of the mass spectrometer, and Ludovic Bruneau (Bourgogne University) for XRD measurement. We owe thanks to Albert Jambon (Paris University) for granting access to the XRF device and to Marc de Rafélis for his help in interpreting the XRD spectra. We are grateful to the French Geological Survey (BRGM) for the kind permission to access to the core repository at Orléans. We thank Tim Lyons and Chris Pearce for comments on a previous version of this manuscript, and Jeremy Owens and an anonymous referee for the insightful suggestions they made to improve this current manuscript. M. Hermoso was funded by NERC through postdoctoral fellowship (NE/H015523/1).

Edited by: A. Sluijs

\section{References}

Algeo, T. J. and Lyons, T. W.: Mo - total organic carbon covariation in modern anoxic marine environments: Implications for analysis of paleoredox and paleohydrographic conditions, Paleoceanography, 21, PA1016, doi:10.1029/2004PA001112, 2006.

Al-Suwaidi, A., Angelozzi, G. N., Baudin, F., Damborenea, S. E, Hesselbo, S. P., Jenkyns, H. C., Manceñido, M. O., and Riccardi A. C: First record of the Early Toarcian oceanic anoxic event from the Southern Hemisphere, Neuquén Basin, Argentina, J. Geol. Soc., 167, 633-636, doi:10.1144/0016-76492010-025, 2010.

Boulila, S., Galbrun, B., Miller, K. G., Pekar, S. F., Browning, J. V., Laskar, J. and Wright, J. D.: On the origin of Cenozoic and Mesozoic "third-order" eustatic sequences, Earth-Sci. Rev., 109, 94-112, doi:10.1016/j.earscirev.2011.09.003, 2011.

Carter, E. S., Goričan, Š., Guex, J., O’Dogherty, L., De Wever, P., Dumitrica, P., Hori, R. S., Matsuoka, A., and Whalen, P. A.: Global radiolarian zonation for the Pliensbachian, Toarcian and Aalenian, Palaeogeogr. Palaeoecl., 297, 401-419, doi:10.1016/j.palaeo.2010.08.024, 2010.

Caruthers, A. H., Gröcke, D. R. and Smith, P. L.: The significance of an Early Jurassic (Toarcian) carbon-isotope excursion in Haida Gwaii (Queen Charlotte Islands), British Columbia, Canada, Earth Planet. Sc. Lett., 307, 19-26, doi:10.1016/j.eps1.2011.04.013, 2011.

Coe, A. L.: The record of sea level change in the sedimentary record, Cambridge University Press, Cambridge, 2003.

Cohen, A. S., Coe, A. L., and Harding, S. M.: Osmium isotope evidence for the regulation of atmospheric $\mathrm{CO}_{2}$ by continental weathering, Geology, 32, 157-160, doi:10.1130/G20158.1, 2004.

de Graciansky, J. C., Hardenbol, J., Jacquin, T., and Vail, P. R. (Eds): Mesozoic and Cenozoic Sequence Stratigraphy of European basins: SEPM Spec. Pub. 60, Tulsa, Oklahoma, 1998.
Dera, G., Pellenard, P., Neige, P., Deconinck, J.-F., Pucéat, E., and Dommergues, J.-L.: Distribution of clay minerals in Early Jurassic Peritethyan seas: Palaeoclimatic significance inferred from multiproxy comparisons, Palaeogeogr. Palaeoecl., 271, 39-51, doi:10.1016/j.palaeo.2008.09.010, 2009.

De Wever, P. and Baudin, F.: Palaeogeography of radiolarite and organic-rich deposits in Mesozoic Tethys, Geol. Rundsch., 85, 310-326, 1996.

Erba, E.: Calcareous nannofossils and Mesozoic oceanic anoxic events, Mar. Micropaleontol., 52, 85-106, 2004.

Erba, E.: The first 150 million years history of calcareous nannoplankton: Biosphere - geosphere interactions, Palaeogeogr. Palaeocl., 232, 237-250, 2006.

Gély, J. and Lorenz, J.: Lias and Dogger series of the Paris Basin (France): syn-sedimentary tectonic and palaeogeographic reconstructions for each ammonite biozonation level, Geobios, 39, 631-649, doi:10.1016/j.geobios.2005.06.005, 2006.

Gill, B. C., Lyons, T. W., and Jenkyns, H. C.: A global perturbation to the sulfur cycle during the Toarcian Oceanic Anoxic Event, Earth Planet. Sc. Lett., 312, 484-496, doi:10.1016/j.epsl.2011.10.030, 2011.

Gröcke, D. R., Hori, R. S., Trabucho-Alexandre, J., Kemp, D. B., and Schwark, L.: An open ocean record of the Toarcian oceanic anoxic event, Solid Earth, 2, 245-257, doi:10.5194/se-2-2452011, 2011.

Guillocheau, F., Robin, C., Allemand, P., Bourquin, S., Brault, N., Dromart, G., Friedenberg, R., Garcia, J.-P., Gaulier, J.-M., Gaumet, F., Grosdoy, B., Hanot, F., Le Strat P., Mettraux, M., Nalpas, T., Prijac, C., Rigollet, C., Serrano, O., and Grandjean, G.: Meso-Cenozoic geodynamic evolution of the Paris Basin: 3D stratigraphic constraints, Geodin. Acta, 13, 189-245, 2000.

Hallam, A.: A review of the broad pattern of Jurassic sea-level changes and their possible causes in the light of current knowledge, Palaeogeogr. Palaeocl., 167, 23-37, doi:10.1016/S00310182(00)00229-7, 2001.

Hermoso, M., Le Callonnec, L., Minoletti, F., Renard, M., and Hesselbo, S. P.: Expression of the Early Toarcian negative carbon-isotope excursion in separated carbonate microfractions (Jurassic, Paris Basin), Earth Planet. Sc. Lett., 277, 194-203, doi:10.1016/j.eps1.2008.10.013, 2009a.

Hermoso, M., Minoletti, F., Le Callonnec, L., Jenkyns, H. C., Hesselbo, S. P., Rickaby, R. E. M., Renard, M., de Rafélis, M., and Emmanuel, L.: Global and local forcing of Early Toarcian seawater chemistry: A comparative study of different paleoceanographic settings (Paris and Lusitanian basins), Paleoceanography, 24, 1-15, doi:10.1029/2009PA001764, 2009b.

Hermoso, M., Minoletti, F., Rickaby, R. E. M., Hesselbo, S. P., Baudin, F., and Jenkyns, H. C.: Dynamics of a stepped carbonisotope excursion: Ultra high-resolution study of Early Toarcian environmental change, Earth Planet. Sc. Lett., 319-320, 45-54, doi:10.1016/j.eps1.2011.12.021, 2012.

Hesselbo, S. P.: Sequence stratigraphy and inferred relative sealevel change from the onshore British Jurassic, Proceedings of the Geologists' Association, 119, 19-34, doi:10.1016/S00167878(59)80069-9, 2008.

Hesselbo, S. P., Gröcke, D., Jenkyns, H., Bjerrum, C., Farrimond, P., Morgans Bell, H. S., and Green, O.: Massive dissociation of gas hydrate during a Jurassic oceanic anoxic event, Nature, 406, 392-395, doi:10.1038/35019044, 2000. 
Hori, R. S.: The Toarcian radiolarian event in bedded cherts from southwestern Japan, Mar. Micropaleontol., 30, 159-169, doi:10.1016/S0377-8398(96)00024-2, 1997.

Izumi, K., Miyaji, T., and Tanabe, K.: Early Toarcian (Early Jurassic) oceanic anoxic event recorded in the shelf deposits in the northwestern Panthalassa: Evidence from the Nishinakayama Formation in the Toyora area, west Japan, Palaeogeogr. Palaeocl., 315-316, 100-108, doi:10.1016/j.palaeo.2011.11.016, 2012.

Jenkyns, H. C.: The Early Toarcian (Jurassic) Anoxic Event, Am. J. Sci., 288, 101-151, 1988.

Jenkyns, H. C.: Geochemistry of oceanic anoxic events, Geochem. Geophy. Geosy., 11, 1-30, doi:10.1029/2009GC002788, 2010.

Jenkyns, H. C., Jones, C. E., Gröcke, D. R., Hesselbo, S. P., and Parkinson, D. N.: Chemostratigraphy of the Jurassic System: applications, limitations and implications for palaeoceanography, J. Geol. Soc., 159, 351-378, doi:10.1144/0016-764901-130, 2002.

Kemp, D., Coe, A., Cohen, A., and Schwark, L.: Astronomical pacing of methane release in the Early Jurassic period, Nature, 437, 396-399, doi:10.1038/nature04037, 2005.

Kemp, D., Coe, A. L., Cohen, A. S., and Weedon, G. P.: Astronomical forcing and chronology of the early Toarcian (Early Jurassic) oceanic anoxic event in Yorkshire, UK, Paleoceanography, 26, PA4210, doi:10.1029/2011PA002122, 2011.

Lézin, C., Andreu, B., Pellenard, P., Bouchez, J.-L., Emmanuel, L., Fauré, P., and Landrein, P.: Geochemical disturbance and paleoenvironmental changes during the Early Toarcian in NW Europe, Chem. Geol., 341, 1-15, doi:10.1016/j.chemgeo.2013.01.003, 2013.

Lorenz, C.: Forage scientifique de Sancerre-Couy, Cher: Terrains sédimentaires, Doc. BRGM, 136, Orléans, France, 185 pp., 1987.

Lu, Z., Jenkyns, H. C., and Rickaby, R. E. M.: Iodine to calcium ratios in marine carbonate as a paleo-redox proxy during oceanic anoxic events, Geology, 38, 1107-1110, doi:10.1130/G31145.1, 2010.

McArthur, J. M., Algeo, T. J., van de Schootbrugge, B., Li, Q., and Howarth, R. J.: Basinal restriction, black shales, Re-Os dating, and the Early Toarcian (Jurassic) oceanic anoxic event, Paleoceanography, 23, PA4217, doi:10.1029/2008PA001607, 2008.
McElwain, J. C., Wade-Murphy, J., and Hesselbo, S. P.: Changes in carbon dioxide during an oceanic anoxic event linked to intrusion into Gondwana coals, Nature, 435, 479-482, doi:10.1038/nature03618, 2005.

Morard, A., Guex, J., Bartolini, A., Morettini, E., and de Wever, P.: A new scenario for the Domerian - Toarcian transition, Bull. Soc. Géol. Fr., 174, 351-356, doi:10.2113/174.4.351, 2003.

Neuendorf, K. K. E., Mehl Jr., J. P., and Jackson, J. A.: Glossary of Geology, American Geological Institute, Alexandria, 779 pp., 2005.

Pearce, C. R., Cohen, A. S., Coe, A. L., and Burton, K. W.: Molybdenum isotope evidence for global ocean anoxia coupled with perturbations to the carbon cycle during the Early Jurassic, Geology, 36, 231-234, doi:10.1130/G24446A.1, 2008.

Röhl, H.-J., Schmid-Röhl, A., Oschmann, W., Frimmel, A., and Schwark, L.: The Posidonia Shale (Lower Toarcian) of SWGermany: an oxygen-depleted ecosystem controlled by sea level and palaeoclimate, Palaeogeogr. Palaeocl., 165, 27-52, doi:10.1016/S0031-0182(00)00152-8, 2001.

Tribovillard, N., Algeo, T. J., Lyons, T., and Riboulleau, A.: Trace metals as paleoredox and paleoproductivity proxies: An update, Chem. Geol., 232, 12-32, doi:10.1016/j.chemgeo.2006.02.012, 2006.

Wignall, P. B., Newton, R. J., and Little, C. T. S.: The timing of paleoenvironmental change and cause-and-effect relationships during the early Jurassic mass extinction in Europe, Am. J. Sci., 305, 1014-1032, doi:10.2475/ajs.305.10.1014, 2005.

Williams, C. J., Hesselbo, S. P., Jenkyns, H. C., and MorgansBell, H. S.: Quartz silt in mudrocks as a key to sequence stratigraphy (Kimmeridge Clay Formation, Late Jurassic, Wessex Basin, UK), Terra Nova, 13, 449-455, doi:10.1046/j.13653121.2001.00378.x, 2001.

Woodfine, R. G., Jenkyns, H. C., Sarti, M., Baroncini, F., and Violante, C.: The response of two Tethyan carbonate platforms to the early Toarcian (Jurassic) oceanic anoxic event: environmental change and differential subsidence, Sedimentology, 55, 10111028, 2008. 